\title{
Some unresolved complexities in matters involving paternity: a South African Perspective
}

I would like to dedicate this article to the late Professor Francois de Villiers.

\section{Introduction}

One of the most controversial issues regarding paternity in South Africa is whether the courts are empowered to order a relevant party to submit to DNA/blood tests ${ }^{1}$. A number of cases concerning this issue were decided either in terms of the common law or in terms of the Children's Status Act ${ }^{2}$, the Constitution of the Republic of South Africa ${ }^{3}$ and/or the Children's Act ${ }^{4}$. The inconsistency among these decisions regarding a court's power to order an adult and a child to undergo these tests ${ }^{5}$ has led to major problems. Consequently, it was a matter that needed the SCA's assistance and guidance.

The article will illustrate that the long awaited SCA decision in $Y M v L B^{6}$ resulted in more questions than answers, and that South Africa is no closer to resolving issues pertaining to paternity. The article briefly discusses the South African common law position, the effect of the Constitution, the position regarding paternity as regulated by the Children's Act, followed by a discussion of the decision of the High Court in $L B v$ $Y D^{7}$ and the SCA's decision in $Y M v L B$. This will be followed by a critique of the SCA judgment, by highlighting some of the complexities in paternity matters that remain

1 T. Boezaart, Law of Persons, Claremont 2010, p. 102.

282 of 1987.

3 Of the Republic of South Africa, 1996, hereafter: the Constitution.

438 of 2005.

5 Vid. T. Boezaart, Law of Persons, Claremont 2010, p. 102-105 in this regard.

62010 (6) SA 338 (SCA). (Hereafter YM v LB).

72009 (5) SA 463 (T). 
unresolved within the South African law context with the aim of paving the way for future comparative research on this topic.

\section{Determining paternity in terms of the common law}

In answering the question as to who is presumed to be the father of a child the common law distinguishes between the scenarios where the mother is married or unmarried. The importance of this distinction is illustrated by the different presumptions, which operate in respect of each scenario.

If a married woman gives birth to a child her spouse is deemed to be the father of the child. The pater est quem nuptiae demonstrant maxim means that marriage indicates who the father is ${ }^{8}$. The presumption applies if the parties were married at the time of the child's conception, birth, or at any intervening time'; thus even, if the child was conceived before or during the marriage but was born after its dissolution ${ }^{10}$. As this presumption is rebuttable, the husband is presumed to be the father unless he can prove otherwise ${ }^{11}$. This he can do at any time, by relying on the following factors: the absence of (or inability to have) sexual intercourse ${ }^{12}$; his sterility ${ }^{13}$; the gestation period $^{14}$; and DNA/blood tests ${ }^{15}$. The argument that a contraceptive was used during the relevant time cannot be used as a determining factor to adduce that a particular man is not the child's father ${ }^{16}$. This similarly applies to relying on physical features ${ }^{17}$. Furthermore, a man who

8 T. Boezaart Law of Persons, Juta: Claremont 2010, p. 99; J. Heaton, The South African Law of Persons, LexisNexis: Durban 2012, p. 54.

9 T. Boezaart Law of Persons, Juta: Claremont 2010, p. 99; J. Heaton, The South African Law of Persons, LexisNexis: Durban 2012, p. 54.

10 T. Boezaart Law of Persons, Juta: Claremont 2010, p. 99.

11 T. Boezaart Law of Persons, Juta: Claremont 2010, p. 99; J. Heaton, The South African Law of Persons, LexisNexis: Durban 2012, p. 55.

12 T. Boezaart Law of Persons, Juta: Claremont 2010, p. 100; J. Heaton, The South African Law of Persons, LexisNexis: Durban 2012, p. 57.

13 T. Boezaart Law of Persons, Juta: Claremont 2010, p. 101; J. Heaton, The South African Law of Persons, LexisNexis: Durban 2012, p. 58.

14 Establishing the period of gestation is relied on often to determine whether a particular man is the father of the child. There is no fixed period of gestation and South African courts make decisions on an ad hoc basis, at times relying on medical evidence or at others, taking judicial notice of the normal period of gestation: J. Heaton, The South African Law of Persons, LexisNexis: Durban 2012, p. 58.

15 T. Boezaart Law of Persons, Juta: Claremont 2010, p. 101-106; J. Heaton, The South African Law of Persons, LexisNexis: Durban 2012, p. 57-65. Rex v Pie 19483 SA 1117 (O) 1118 where the Court confirmed that blood tests could be used as a means to confirm or deny paternity.

16 T. Boezaart Law of Persons, Juta: Claremont 2010, p. 107.

17 T. Boezaart Law of Persons, Juta: Claremont 2010, p. 106-107; J. Heaton, The South African Law of Persons, LexisNexis: Durban 2012, p. 58-59. 
admits that he had intercourse with a woman during the possible time of conception, but alleges and proves that the woman had sex with another man or other men during the relevant time cannot rely on this evidence, as the defence of the exceptio plurium concubentium does not form part of our law ${ }^{18}$.

In respect of an unmarried woman, once sexual intercourse at any time with the mother was proven or admitted ${ }^{19}$, the man was presumed to be the father, unless he could disprove paternity on a balance of probabilities by relying on the abovementioned factors ${ }^{20}$.

\section{The Children's Status Act ${ }^{21}$}

The position in respect of children born of unmarried parents was regulated by section 1 of this Act, which provided:

If in any legal proceedings at which it has been placed in issue whether any particular person is the father of an extra-marital child it is proved by way of a judicial admission or otherwise that he had sexual intercourse with the mother of the child at any time when that child could have been conceived, it shall, in the absence of evidence to the contrary, be presumed that he is the father of the child.

This section altered the common law position, in that proof or admission of sexual intercourse with the mother at any time other than at a time material to conception no longer raised a presumption of paternity. Furthermore, the presumption operated only in the absence of evidence to the contrary ${ }^{22}$.

It was further provided by section 2 of the Act that:

If in any legal proceedings at which the paternity of any child has been placed in issue, it is adduced in evidence or otherwise that any party to those proceedings, after he has been requested thereto by the other party to those proceedings, refuses to submit himself or, if he has parental authority over that child, to cause that child to be submitted to the taking of a blood sample in order to carry out scientific tests

18 J. Heaton, The South African Law of Persons, LexisNexis: Durban 2012, p. 58.

19 B. Van Heerden et al, Boberg's law of persons and the family, Juta: Kenwyn 1999, p. 365.

20 T. Boezaart Law of Persons, Juta: Claremont 2010, p. 108-109. The onus that an alleged father bore was strict as can be seen from Mohamed $v$ Shaik 19784 SA 523 (N) 526D where it was said that the type of evidence relied upon by the putative father to rebut the presumption must not merely prove that he is probably not the father, but that he could not possibly be the father.

21 The Children's Status Act was repealed by the Children's Act.

22 B. Van Heerden et al, Boberg's law of persons and the family, Juta: Kenwyn 1999, p.367. 
relating to the paternity of that child, it shall be presumed, until the contrary is proved, that any such refusal is aimed at concealing the truth concerning the paternity of that child.

This section merely created a presumption, and did not impose an obligation on a party to subject him or herself or the child to blood tests nor did it confer on our courts a statutory power to order that parties to a paternity dispute submit themselves or their child to such tests ${ }^{23}$. Thus, if sexual intercourse with the alleged father at the relevant time was proven, section 2 merely created a presumption that the person's refusal was aimed at concealing the truth. The reality of the situation where a mother refused to submit herself and the child to a blood test was, consequently that a blood test could not be used to confirm the truth, nor to deny it because an unco-operative mother or alleged father could not be compelled to submit herself or himself or the child to a blood test.

\title{
The Children's Act
}

Section 36 of the Children's Act provides for a presumption of paternity of a child born to unmarried parents. It states that:

\begin{abstract}
If in any legal proceedings in which it is necessary to prove that a particular person is the father of a child born out of wedlock ${ }^{24}$ it is proved that that person had sexual intercourse with the mother of the child at any time when that child could have been conceived, that person is, in the absence of evidence to the contrary which raises a reasonable doubt, presumed to be the biological father of the child.
\end{abstract}

The presumption created in this section is of course rebuttable. However, the onus of proof of the rebuttal required by the section is a departure from the ordinary rule in civil proceedings, namely, on a balance of probabilities. To rebut the presumption, any acceptable evidence will suffice, whether direct or circumstantial, provided that it is sufficient to raise a reasonable doubt ${ }^{25}$. The provision sets the bar higher than that provided in terms of section 2 of the Children's Status Act ${ }^{26}$. Section 37 of the Children's Act provides further that:

23 B. Van Heerden et al, Boberg's law of persons and the family, Juta: Kenwyn 1999, p. 387-388.

24 The correct terminology for such child would be a child born of unmarried parents.

25 J. Heaton, The South African Law of Persons, Durban 2012, p. 57.

26 The constitutionality of this provision in respect of the onus it creates has come under scrutiny. J. Heaton, The South African Law of Persons, Durban 2012, p. 57 argues that the discrepancy between the onus placed on a married man as opposed to the onus placed on an unmarried man amounts to an unjustifiable infringement of the right to equality and equal protection and benefit of the law. 
If a party to any legal proceedings in which the paternity of a child has been placed in issue has refused to submit himself or herself, or the child, to the taking of a blood sample in order to carry out scientific tests relating to the paternity of the child, the court must warn such party of the effect which such refusal might have on the credibility of that party.

It is argued that the motivation for submitting to blood tests in terms of this section appears to be weaker than that which operated under the Children's Status $\mathrm{Act}^{27}$. In other words, whereas the earlier Act created a presumption that the mother or putative father was allegedly concealing the truth, the Children's Act merely creates a presumption in respect of either's credibility as a witness.

Section 26 of the Children's Act provides for the procedure in instances where a man wishes to be identified as the father. It provides for a man who claims paternity to either bring an application for an amendment to the registration of birth of the child so as to be identified as the father (provided that the mother consents) or to apply to court for an order confirming paternity if the mother refuses to an amendment; if she is incompetent to give consent due to mental illness; cannot be located; or is deceased ${ }^{28}$. The section does not apply to the biological father of a child who was conceived through rape of or incest with the child's mother or to the gamete donor for purposes of artificial fertilisation ${ }^{29}$.

Section 20 of the Act provides that the biological father has full parental responsibilities and rights if he was married to the mother at the time of birth or conception or at any intervening time. Bonthuys argues that the effect of this provision on the marital presumption is unclear and confusing as it is not apparent how the presumption of paternity would operate where a non-biological father is married to the mother during the relevant times ${ }^{30}$.

Unmarried fathers may acquire automatic parental responsibilities and rights by meeting the requirements of section 21 of the Children's Act. How this section operates in respect of another man acquiring responsibilities and rights in respect of a child through the marital presumption is not clarified in terms of the $\mathrm{Act}^{31}$.

\section{Relevant Constitutional Provisions}

The relevant sections of the Constitution that come into play in matters involving paternity are section 14 (the right to privacy); section 10 (the right to dignity); section 12

27 J. Heaton et. al., Commentary on the Children's Act, Juta: Wetton 2007, ch. 3, p. 40.

28 Section 26(1)(a) and (b) of the Children's Act.

29 Section 26(2) of the Children's Act.

30 E. Bonthuys, What you don't know can't hurt you: the Supreme Court of Appeal and the presumptions of paternity, "South African Law Journal" 2011, p. 430-433.

31 E. Bonthuys, What you don't know can't hurt you: the Supreme Court of Appeal and the presumptions of paternity, "South African Law Journal" 2011, p. 431. 
(the right to security of the person and bodily integrity); and section 28 (the rights of children) which in terms of subsection (2) provides that in any matter involving a child, the best interests of such child is of paramount importance ${ }^{32}$. Section 36 of the Constitution is also of relevance as it provides that rights contained in the Bill of Rights may be limited in terms of law of general application if the limitation is reasonable and justifiable in an open and democratic society.

\section{South African Case Law}

Since there were no clear legislative provisions regarding whether South African courts have the power to compel a mother and/or a child to submit to paternity tests, it was left to the courts to determine this issue ${ }^{33}$. However, South African courts were inconsistent regarding a court's powers to compel an adult ${ }^{34}$ and/or a child ${ }^{35}$ to submit to blood tests. Other inconsistencies relate to maintenance ${ }^{36}$ being paid for a child that could possibly not be one's own, and the question whether the courts should uphold an individual's right to privacy (and/or dignity) or seek the truth in pursuit of the proper administration of justice ${ }^{37}$. Clarity was thus required, and the hope was that the SCA would assist in this regard.

32 B. Van Heerden, et al Boberg's law of persons and the family, Juta: Kenwyn 1999, p. 382.

33 J. Heaton, The South African Law of Persons, LexisNexis: Durban 2012, p. 60.

$34 \mathrm{Vid}$. for example $M v R 19891 \mathrm{SA} 416(\mathrm{O})$ 428D in which it was held that it fell within a court's inherent powers, as a procedural matter to compel an adult to submit to the relevant test. Compare however, Nell v Nell 19903 SA 889 (T) 895F-H and D v K 19972 BCLR 209 (N) $216 \mathrm{E}$ where it was held that compelling an adult to submit to a blood test is not purely procedural in nature.

35 Vid. for example O v O 19924 SA 137 (C) 139G-H; Mv R 421E-F; Seetal v Pravitha 19833 SA 827 (D) $862 \mathrm{H}-863 \mathrm{H}$ where the Court held that it could override a guardian's refusal to consent to a minor submitting to a blood or DNA test. Compare, however, $S$ v L 19923 SA 713 (E) 721I-722A where the Court held that it does not have the power to interfere with a guardian's decision.

36 Vid. for example Seetal v Pravitha 865G-866A where the Court acknowledged that there was a possibility that the alleged father would not show affection towards the child and continue denying paternity. Nevertheless, the Court was satisfied that the child would be maintained. However, in $M v R 422 \mathrm{E}-\mathrm{H}$ it was held that courts should not regard instances where a man is wrongly paying money for a child that is not his as a benefit that should be considered.

37 In $S v L 860 \mathrm{H}-861 \mathrm{~F} ; M v R 423 \mathrm{E}$ where the Court acknowledged that compelling an adult to submit to blood tests results in a conflict between the discovery of truth and the right to privacy of the adult involved. In Dv K1997 2 BCLR 209 (N) 217D-G it was held that as far as the conflict involved in such matters, a Court should always strive to achieve these ideals and that one should not be maintained at the expense of the other. The correct approach would be to assist an applicant only if a Court is satisfied that justice will not be achieved unless the relief is granted. 


\section{$L B \mathrm{v} Y D$ AND $Y M v L B$}

\section{Facts}

The case involved parties who had an intimate relationship at a time when the child was conceived. However, the relationship soured as a result of the respondent' $\mathrm{s}^{38}$ conduct and the appellant ${ }^{39}$ remarried resumed a relationship with a previous partner, whom she later married while pregnant with the alleged child of the respondent. The respondent had on occasions denied paternity and retracted this denial. Upset by the denial, the appellant had on one occasion also informed the respondent that he was not the father of the child. In response, the respondent admitted paternity, but requested that the appellant and the child submit to a DNA test to clarify the situation. She refused to do so, which resulted in the respondent requesting a court order that she and the child submit to the test.

\section{The decision by the High Court}

The Court stated that when considering these types of applications, the need to protect the privacy and bodily integrity of those who are requested to submit to the test, is taken into account as well as a court's role in discovering the truth whenever possible through the use of scientific methods ${ }^{40}$.

With regard to minors, the court as upper guardian has the power to authorise a blood test on such a child, despite objections by a primary caregiver. However, when granting such an order a court must act in what it considers to be the best interests of the child ${ }^{41}$.

It was also said that truth is a primary value in the administration of justice and should be pursued as where we come from and who we are fall within the realm of the sacred for most people. Furthermore, to exclude reliable scientific evidence because it would involve a minor infringement of privacy will more often than not harm the legitimacy of the administration of justice ${ }^{42}$.

According to the Court the discovery of truth should prevail over the idea that the rights of privacy and bodily integrity should be respected, and that it would more often than not be in the best interests of the child to have any doubts about true paternity resolved by resorting to the best available evidence ${ }^{43}$. Although an adult's or child's rights to privacy and dignity should not be sacrificed to the needs of the administration of justice, they should yield to the proper administration of justice when it is reasonable

\footnotetext{
$38 \mathrm{LB}$

39 YD, later YM.

40 469B-C.

41 469D.

42 469J-470A-D.

43 471A-B.
} 
and justifiable to do so, taking into account the importance of the purpose and necessity of establishing the truth ${ }^{44}$.

The Court then proceeded to deal with the relevant constitutional rights at stake and held that the best interests of the child should trump the rights to dignity and privacy unless there are compelling reasons to the contrary ${ }^{45}$.

With reference to the changes brought about by the Children's Act in respect of the unmarried biological father ${ }^{46}$, it was stated that the significant change in policy regarding the rights and responsibilities of such fathers brings added importance to the need for scientific determination of paternity, as it could result in automatic rights and responsibilities being bestowed on them. ${ }^{47}$

According to the Court, sections 36 and 37 of the Children's Act do not detract from the fact that a court is possessed inherently and constitutionally of a jurisdiction to order parties to have blood tests when it concludes that the competing rights and interests at play require the truthful verification of paternity by scientific means ${ }^{48}$. The adverse inference contained in section 37 of the Children's Act, does not provide the positive confirmation and reliance, and an inference would merely produce a finding that the applicant is the father, when he instead wishes to eliminate the possibility that he is not the father. Furthermore, considering the extended rights and responsibilities that have been afforded to unmarried fathers, it is important that the truth be established to avoid burdening a party with responsibilities that might not be his to bear ${ }^{49}$.

Regarding whether or not it would be in the best interests of the minor child to determine paternity with certainty, it was found that this was indeed a case that required clarification: both parties have at one point or another admitted and denied that the applicant (respondent) was the biological father; the respondent (appellant) had been intimate with her husband during the period of possible conception; and the child was very young, thus, no established relationship would be disturbed or harmed should it be found that the applicant (respondent) was not the father. Furthermore, confirmation of paternity at this stage would remove the possibility of the dispute arising at a later stage $^{50}$. The respondent (appellant) was thus ordered to submit herself and the minor child to a DNA test in order to establish whether the applicant (respondent) was indeed the biological father of the minor child.

\footnotetext{
44 471C-

45 474F-G.

$46475 \mathrm{G}-476 \mathrm{~F}$.

47 476F-H.

48 477B-C.

49 477B-E.

50 478B-479A.
} 


\section{The SCA decision}

The court a quo decision was subsequently taken on appeal to the $\mathrm{SCA}^{51}$. The SCA relied on the respondent's founding affidavit where he stated that he believed that he was the father of the child and wished to develop a relationship with her $^{52}$. Furthermore the minor disputes between the parties merely related to dates and exchanges between them. The respondent had never denied paternity in his affidavit, he merely sought scientific certainty. According to the SCA, the High Court's finding that the appellant may have been intimate with her husband at a time when the child could have been conceived was unwarranted, as the only evidence was the respondent's statement in his replying affidavit that he had heard from a friend that the appellant had commenced such a relationship at a time when conception had occurred. Thus, paternity was not in dispute ${ }^{53}$.

The SCA held that the issue of paternity was determinable on a balance of probabilities. What the applicant was requesting was scientific proof to which, according to the Court, he was not entitled. The Court, however, confirmed that there may be cases where there is genuine uncertainty as to paternity and a DNA test of the child in question should be ordered. As the upper guardian of children, the Court has the inherent power to order scientific tests if that would be in the best interests of the child. Furthermore, section 37 of the Children's Act anticipates the use of scientific tests to prove paternity, but this was not a case where the Court's inherent power needed to be invoked as paternity was not in dispute ${ }^{54}$.

Regarding the constitutional rights at stake in 'genuine' paternity disputes, the SCA held that the rights to privacy and bodily integrity may be infringed by a procedure ordered by a Court in the exercise of its inherent jurisdiction, if it is in the best interests of the child to do so, as these rights, like others contained in the Constitution, may be limited where it is reasonable and justifiable to do so by applying the criteria provided in section 36(1) of the Constitution. However, the Court once again reiterated that in this case it was unnecessary, whereas in other instances it may well be justifiable to order blood or DNA tests ${ }^{55}$.

The Court proceeded to state that whether the discovery of truth should prevail over such rights is a matter that should not be generalised, and held that it is not always in an individual's interests to know the truth. Where a court is faced with a request to order

51 An application for leave to appeal was brought by the defendant in YD v LB (A) 2009 (5) SA 479 (GNP). However, the appeal was dismissed and consequently resulted in the appeal to the SCA.

$52340 \mathrm{C}$.

53 340H-341A.

54 341B-E. M. Buthelezi, A missed opportunity to settle the law of DNA testing in paternity disputes: $L B$ v YD 20106 SA 338 (SCA) "Obiter" 2011, p. 480 where the author critiques the court's statement regarding section 37.

55 341G-I 
a blood/DNA test, it should consider the position of the particular child and make an order consistent with its determination in respect of that child alone. According to the SCA, a court's role and its duty is to determine disputes in civil matters on a balance of probabilities: it is not the function of a court to ascertain scientific proof of the $\operatorname{truth}^{56}$. The appeal was thus upheld.

Although the High Court's decision has been met with approval by certain legal scholars $^{57}$, the judgment was evidently overturned by the SCA. An issue that has been clarified by the SCA is that the court as upper guardian of minors may override a custodian's refusal to allow a blood/DNA test on a child if it is in the best interests of such child. The Court did not, however, directly address the question of whether it may compel an adult to undergo a blood/DNA test as the appellant's maternity was not and could not be in issue ${ }^{58}$. However, later in the judgment, the Court mentions that in 'actual paternity' disputes, an individual's rights to privacy and physical integrity may be limited if that would be in the best interests of the child involved ${ }^{59}$. It would then appear that the Court answered the question in the affirmative.

There are some core differences between the decisions of the High Court and the SCA. First, the High Court regarded the matter at hand as a paternity dispute, whereas the SCA did not. Secondly, the High Court regarded ascertaining the truth as being vital to the administration of justice, whereas the SCA stated that establishing the truth is not always in one's best interests.

The following are regarded as aspects of paternity, which, it is argued, should have been addressed and/or clarified by the SCA.

\section{Unresolved Complexities}

\section{What is a paternity dispute?}

Although the SCA stated that the matter did not involve a dispute regarding paternity ${ }^{60}$, there was indeed such dispute as the pater est quem nuptiae demonstrant presumption came into play. By virtue of the marital presumption the appellant's husband is deemed the father of the child. It is uncertain why the SCA did not address this issue as in this

56 341A-B.

57 Vid. discussion of High Court decision which was met with approval by W. Banoobhai, and S. Hoctor, The Court's power to compel DNA testing in paternity disputes - LB v YD $20095 \mathrm{SA}$ 463 (T), "Obiter" 2009, p. 791; C.M.A. Nicholson, LB v YD 20095 SA 463 (T) /YD v LB (A) 20095 SA 479 (NGP): Disputed paternity, blood tests; court as upper guardian, compel blood tests for DNA testing: best interests of the child "De Jure" 2010, p. 409.

$58341 \mathrm{~B}$.

$59341 \mathrm{G}-\mathrm{H}$.

$60341 \mathrm{~A}$. 
instance there were two possible fathers. According to Nicholson, the High Court was correct in ordering the DNA tests as reliance on the presumption would have bestowed parental responsibilities and rights on the appellant's husband as a consequence of the marriage ${ }^{61}$. Whether the High Court was correct in not relying on the presumption is a matter that had to be clarified by the SCA, especially in light of the automatic responsibilities and rights that an unmarried father is afforded if the requirements in section 21 of the Children's Act are met ${ }^{62}$. One would have expected a comprehensive analysis of paternity by the SCA, yet one finds that the Court's decision was limited to a statement that the matter at hand was not a paternity dispute. However, the Court does not elaborate on what would constitute a 'genuine' disagreement regarding paternity. According to the SCA the application merely amounted to a 'request for scientific proof of certainty'. The Court did not acknowledge that this so-called 'request' was the result of doubt, regardless of the fact that the respondent had admitted paternity after also having denied it. What the court failed to consider as a factor in its decision was that there was a denial of paternity on the part of the appellant as well, regardless of the reasons she gave for making the statement ${ }^{63}$. Furthermore, if 'uncertainty' regarding fatherhood does not result in a paternity dispute, it is unclear what does and required the SCA's clarification.

\section{Application of the relevant presumptions}

One of the concluding remarks in the note by Buthelezi is that in genuine disputes regarding paternity, the court should strive towards settling the matter on a balance of probabilities and that only in a case where this is not possible, the court should consider whether scientific tests should be resorted to ${ }^{64}$. The fact that a man had sexual intercourse with a woman during the conception period does not mean that he is necessarily the child's father. Ranjith $v$ Sheela ${ }^{65}$ illustrates the point that, although there is a marital

61 C.M.A. Nicholson, LB v YD 20095 SA 463 (T)/YD v LB (A) 20095 SA 479 (NGP): Disputed paternity, blood tests; court as upper guardian, compel blood tests for DNA testing: best interests of the child "De Jure" 2010, p. 417; J. Heaton, "Juta's Quarterly Review" October - December 2009 (4).

62 E. Bonthuys, What you don't know can't hurt you: the Supreme Court of Appeal and the presumptions of paternity, "South African Law Journal" 2011, p. 431 argues that the Children's Act does not govern the situation where an unmarried father acquires automatic rights and responsibilities but another man is afforded these responsibilities and rights by virtue of marriage, which was the scenario in this case.

63 Vid. also E. Bonthuys, What you don't know can't hurt you: the Supreme Court of Appeal and the presumptions of paternity, "South African Law Journal" 2011, p. 428.

64 M. Buthelezi, A missed opportunity to settle the law of DNA testing in paternity disputes: LBv YD 20106 SA 338 (SCA) “Obiter" 2011, p. 487.

6519653 SA 103 (D). It should be noted that the parties were married and voluntarily allowed blood samples to be taken. Vid. also $M N v A J 20133$ SA 26 (WCC) where the test confirmed that the alleged father was in fact not the biological father of the child. 
presumption which results in fatherhood, it does not always mean that the woman's spouse is indeed the father. In this case, the Court found that although it was possible that the first defendant could be the father of the child as a result of the parties having sexual intercourse at the relevant time of conception, the results of the blood tests proved otherwise $^{66}$. Thus, the presumption that operates once sexual intercourse is admitted or proved, adds nothing to the question of paternity; in fact, all it does is place the presumed father in a vulnerable position ${ }^{67}$. Similarly, the marital presumption points to the mother's spouse and if the spouse cannot prove sterility or absence of sexual intercourse, it is unclear how else he can disprove paternity without relying on DNA/blood tests.

\section{The role of the mother}

The role of the mother in issues surrounding the relevant presumptions are also important. A mother could easily identify a particular man as the father, being aware that she had intercourse with more than one man during the conception period. However, if the alleged father admits to having intercourse with her during the relevant time, it is difficult to conceive how he could disprove paternity unless he is sterile. Our courts should reconsider the position of the exceptio plurium concubentium especially in light of the constitutional dispensation ${ }^{68}$. It is impossible for a woman to not know that she had intercourse with more than one man at the possible time of conception ${ }^{69}$ whether married or unmarried. Paternity fraud is a reality, and is especially risky for husbands who have been cheated on as well as wealthy and famous $\operatorname{men}^{70}$. However, it seems that South African courts completely disregard this as a factor.

There is also the possibility of a maternity dispute arising. Such dispute can arise in the context of artificial fertilisation. There are cases where the incorrect eggs are implanted in the birth mother, who then believes that the child is biologically hers, when in reality the child is biologically that of another couple ${ }^{71}$. Similarly, maternity will also be

66 104D-H.

67 Although the exceptio plurium concubentium no longer forms part of our law, it has been argued that a woman having the right to 'choose' the father is unconstitutional as it infringes the rights of the true father. Furthermore, it could also be in contravention of the best interests of the child principle as well as the right of the child to parental care: H. Kruger, et al The law of persons in South Africa, Southern Africa 2010, p. 98.

68 H. Kruger et. al., The law of persons in South Africa, Southern Africa 2010, p. 98.

69 R.K. Henry, The innocent third party: victims of paternity fraud, "Fam. L.Q" 2006-2007 40, p. 74.

70 R.K. Henry, The innocent third party: victims of paternity fraud, "Fam. L.Q" 2006-2007 40, p. 52.

71 Vid. A.M. Noble-Allgire, Switched at the fertility clinic: determining maternal rights when a child is born from stolen of misdelivered genetic material, "Missouri Law Review" 1999 64:3, p. 517. 
in dispute if a baby is switched in hospital ${ }^{72}$. The question now follows whether a mother who disputes maternity will find herself in the same difficulty as a father who disputes paternity?

\section{The need for the mother's sample}

Buthelezi ${ }^{73}$ argues that the court's pronouncement on this aspect could possibly create confusion as parties will no longer be certain as to whether or not a mother's DNA sample is needed or not. If her blood sample is not needed, then the argument regarding infringing her constitutional rights would not apply ${ }^{74}$. However, it would remain relevant insofar as it relates to a man refusing to submit himself to the test. If the alleged father refuses to submit to such test it could mean that he has something to hide ${ }^{75}$.

\section{Relevance of the Children's Act provisions}

Of importance is that the SCA highlighted that being certain about paternity is not a right to which an applicant is entitled. A question that comes to mind is how would uncertainty as to paternity be removed if uncertainty is not a sufficient ground to order the tests? A problem with the Court's reasoning in this regard is that the alleged father may be paying maintenance in respect of a child that is not his. If the alleged father is indeed the father, he then has a duty to perform. If he is not the father, then he should not be burdened with responsibilities that are not his to bear ${ }^{76}$. Or should one instead be satisfied that although the particular man may not be the biological father of the child, it would still be in the interests of the child that he or she has access to maintenance? ${ }^{7}$

$72 \mathrm{Vid}$. A.M. Noble-Allgire, Switched at the fertility clinic: determining maternal rights when a child is born from stolen of misdelivered genetic material, "Missouri Law Review"1999 64:3, p. 517.

73 485. However, vid.J. Heaton, The South African Law of Persons, Durban 2012, p. 60 where it is stated that a mother's DNA is not needed to establish paternity.

74485 .

$75 \mathrm{D}$. Singh, The power of the court to compel any person to submit to identification tests in paternity disputes: The unquestionable need for a rule, "De Jure" 1993, p. 123 where it is argued that the mother could have something to hide when refusing to allow the test. This argument could similarly be used in the instance where a man refuses to submit to such a test. Vid. D $v 1997$ 2 BCLR 209 (N) for an example of a case where the man refused to submit to the blood test and relied on his constitutional rights to privacy and freedom of security of the person. The Court in this case refused to grant the order.

$76 \mathrm{Vid}$. for example $M v R 19891 \mathrm{SA} 416$ (O) $422 \mathrm{H}$ where the court stated that the fear that a child may lose the maintenance that he receives from a man who has no duty to provide therefor should not be regarded as factor when making such orders.

$77 \mathrm{Vid}$. also D. Singh, The power of the court to compel any person to submit to identification tests in paternity disputes: The unquestionable need for a rule, "De Jure" 1993, p. 123 where the author argues that "the protection of the child's interest can never justify the protection of a possible falsehood simply so that the child will have a source for money at his/her disposal". 
The other possibility is that a man could pay maintenance for a child that is later proven through paternity tests to not be his. It however appears that there may be a remedy in unjustified enrichment for such father, provided that he proves all the relevant requirements as stated $M N v A f^{7}$.

\section{Parental responsibilities and rights}

The current position may also confer responsibilities and rights on an alleged father in respect of a child that could possibly not be his. This then brings to the fore the question of what is in the best interests of a child: knowing the truth about his or her parentage or believing that a particular man is such a child's father when there is a possibility that this may not be so? Does our law protect the best interests of a child from a legal or biological perspective or both? From a legal perspective, based on the presumptions that operate in respect of married and unmarried mothers, it could be argued that the only interest of a child that is protected is that maintenance is ensured, unless the alleged father can disprove paternity by relying on factors other than DNA/blood tests. This is more so in light of the SCA's statement that paternity was not in issue ${ }^{79}$.

If judicial acknowledgments or admissions are all that is takes to prove paternity, as uncertainty is not the basis for such dispute, it seems that fatherhood is determined legally. That then makes one wonder why the Court did not bestow the appellant's husband with parental responsibilities and rights, if paternity is proven legally as opposed to biologically

\section{A child's right to know his/her genetic origin}

The right to know one's genetic origin is a matter that receives much attention at international level. It is accepted that a child who does not know one or both of his or her biological parents has a vital interest in identifying them ${ }^{80}$. The right to know one's origin means the right to know one's parentage, that is, one's biological family, ascendants and conditions of birth. This right protects each individual's interest to identify where he or she comes from ${ }^{81}$.

7820133 SA 26 (WCC). In this case, the test confirmed that the respondent was not the father of the child he had been maintaining for years. It should be noted that his claim on the basis of unjustified enrichment failed as his particulars of claim did not contain allegations that the mother was enriched at his expense nor that the payments were made without just cause.

79 341A.

$80 \mathrm{~S}$. Besson, Enforcing the child's right to know her origins: contrasting approaches under the Convention on the Rights of the Child and the European Convention on Human Rights, "International Journal of Law, Policy and the Family" 21 2007, p. 138.

$81 \mathrm{~S}$. Besson, Enforcing the child's right to know her origins: contrasting approaches under the Convention on the Rights of the Child and the European Convention on Human Rights, "International Journal of Law, Policy and the Family" 21 2007, p. 140. 
The posed question is: to what extent should South African courts take into account international law and/or foreign law regarding knowing one's genetic origin in their determination of paternity and whether this is indeed possible?

In terms of section 39 (1)(b) of the Constitution, it is provided that when a court interprets the Bill of Rights, it must consider international law. As far as foreign law is concerned, section 39(1)(c) of the Constitution provides that courts may consider foreign law. Furthermore, section 233 of the Constitution provides that every court, when interpreting legislation, must prefer any reasonable interpretation of such legislation that is consistent with international law over any interpretation which is inconsistent with international law.

South African is a party to the Convention on the Rights of the Child ${ }^{82}$ which protects a child's right to know his or her genetic origin in terms of Articles 7 and $8^{83}$. It is thus argued that our courts can in terms of the Constitution consider the relevant Articles of the Convention.

Although South African is not bound by the European Convention on Human Rights the decisions of the European Court could serve as a guideline in determining issues of paternity, especially relating to a child knowing the biological truth of his or her father ${ }^{84}$.

Unfortunately, the SCA did not consider a child's right to know his or her genetic origin, other than providing that it is not always in the best interests of a person to know the truth. The High Court on the other hand would appear to have delved into this question by stating the following:

Where we come from and who we are, for most people, are questions within the realm of the sacred ${ }^{85}$.

It is argued that the right to know one's origin should in future be considered by South African courts since the Constitution ${ }^{86}$ further provides that a child has the right to 'parental' care. The term 'parental' means the care that is ordinarily associated with or similar in nature to care provided by a biological parent or the biological parents in

821989 ratified by South Africa on 16 June 1995.

$83 \mathrm{Vid}$. S. Besson, Enforcing the child's right to know her origins: contrasting approaches under the Convention on the Rights of the Child and the European Convention on Human Rights, "International Journal of Law, Policy and the Family" 21 2007, p. 142-143.

84 Vid. also L. Schäfer, Child Law in South Africa: domestic and international perspectives, Durban 2011, p. 233.

85 470B.

$86 \mathrm{~S} 28(1)(\mathrm{b})$. 
respect of their offspring ${ }^{87}$. The Children's Act further provides that the best interests of the child require that the child maintain a connection with inter alia, his/her family ${ }^{88}$.

Section 7(d)(i) of the Children's Act also takes into account the likely effect on the child of any change in such child's circumstances, including the effect on the child of any separation from both parents or either parent. There is a possibility that the child's biological father may not want to acknowledge the child, but the same can be said of the legal father. This is the more so in those instances where the man is uncertain of his paternity. Erasmus J for example, in $S v L$ commented in his minority judgment as follows:

Fathers who accept their illegitimate children are far more likely to fulfil their duty of support, than are men who are in doubt as to whether the child is theirs. The psychological benefits to the child of certainty as to the identity of its biological father are obvious ${ }^{89}$.

South African courts look at the interests of the child at a particular moment, failing to take into account various possibilities, for example, paternity remaining an issue long after an order requesting a test has been denied ${ }^{90}$. It is unclear how refusing an order that the parties submit to the tests will remove the dispute that resulted in the party requesting a test in the first place.

One has to consider the SCA's statement that knowing the truth is not always beneficial to individuals and/or children. It is not always in one's interest to find out the truth, but how is not knowing any better? DNA/blood tests should not be regarded as the 'ends' which the administration of justice seeks. Instead, it should serve as the 'means' to attain the 'end', the end not only being truth and justice ${ }^{91}$ but a decision which will be

87 A. Louw, The constitutionality of a biological father's recognition as a parent "Potchefstroom Electronic Law Journal" 2010 (13) 3, p. 188.

88 Section 7(f)(ii).Vid. also E. Bonthuys, What you don't know can't hurt you: the Supreme Court of Appeal and the presumptions of paternity, "South African Law Journal" 2011, p. 435 where she states that this factor could be used in favour of paternity testing.

$89 S v L 19923$ SA 713 (E) at 723I, where the judge refers to the study conducted by the South African Law Reform Commission, and comments made by the judge in $M v R 19891 \mathrm{SA} 416$ $(\mathrm{O})$.

90 Vid. YD v LB (A) 20095 SA 479 (GNP): "As matters presently stand, the child's paternity is contested. Without scientific verification it is likely to remain contested for some time. That truth (the contested nature of her paternity) may or may not be revealed to or concealed from the child, but the ongoing contested nature of the paternity will result in the possibility of stigma and the inability of any court to decide on the nature and extent of any financial or other responsibilities owing by the applicant to the child. The ongoing uncertainty will be in neither the applicant's nor the child's best interests." 482D-H.

91 J.L. Taitz, P. Singh, Does the Supreme Court enjoy the inherent power to order the relevant parties to submit to blood tests to establish paternity? "Tydskrif vir Hedendaagse Romeins-Hollandse Reg” 1998 58, p. 95. 
in the best interests of the particular child. The truth will reveal that the alleged father is or is not the biological father of the child and provide the child with certainty regarding his or her genetic origin. Justice would be served by ensuring that a particular relationship is not built between a child and a man that may not be his or her biological parent and fulfilling duties that are not his. Furthermore, the best interests of a child cannot be served by perpetuating a possible fraud. Instead, the best interests of a child in establishing paternity should only lie in finding such child's biological parent ${ }^{92}$.

\section{Benefits of knowing one's genetic origin}

$\mathrm{McRae}^{93}$ argues that children who are deprived of knowing a biological parent or having a relationship with such a parent could grieve that parent's loss even if he/she has never met or been in contact with such parent. There are several potential consequences that could arise in respect of children who go through this process: such a child could become angry, argumentative, oppositional, and exhibit disruptive and disturbing behaviour. She further states that until such a child is able to at least identify his/her biological parent(s), he/she will be unable to complete the grieving process and will continue to display these symptoms. These children may also experience genealogical bewilderment, which is regarded as the feeling of being deprived of one's heritage, religious background, culture and/or race. Thus, knowing one's biological history would enable children to build their self-identities ${ }^{94}$.

According to the SCA it is apparently not a court's duty to ascertain scientific proof of the truth. However, it is its duty to act in the best interests of a child which will be best achieved, it is argued, by relying on the scientific methods available ${ }^{95}$. If the child is young and no relationship has formed, then there is no risk that the interests of the child will be harmed ${ }^{96}$. If a relationship has formed between the child and the alleged father and the test is negative, the mother should inform the child as to 'who' his or her father possibly is ${ }^{97}$ and assist him or her in building a relationship with his or her biological

92 R.K. Henry, The innocent third party: victims of paternity fraud, "Fam. L.Q" 2006-2007 40, p. 68.

93 D. McRae, Evaluating the effectiveness of the best interests marital presumption of paternity: is it actually in the best interests of children to divorce the current application of the best interests marital presumption of paternity, "Whittier J. Child and Fam. Advoc" 2005-2006 5, p. 345.

94 D. McRae, Evaluating the effectiveness of the best interests marital presumption of paternity: is it actually in the best interests of children to divorce the current application of the best interests marital presumption of paternity "Whittier J. Child and Fam. Advoc" 2005-2006 5, p. 378-379.

95 As acknowledged by the court a quo. DNA can confirm whether a particular man is the father of a child with almost $100 \%$ accuracy: W. Banoobhai, and S. Hoctor, The court's power to compel DNA testing in paternity disputes - LB v YD 20095 SA 463 (T), “Obiter" 2009, p. 794.

96 As considered by court a quo.

$97 M v R 19891 \mathrm{SA} 416(\mathrm{O})$ 422G. 
father, if possible. If not possible, justice cannot be served by simply imposing duties on a man who is not the father of the child. It appears as if the SCA attempted to hide behind its statement that the matter is not a paternity dispute to avoid all the complications that come with paternity.

Knowing one's genetic origin is also important for medical purposes as it assists in diagnosing and treating genetically based diseases. A lack of a parent's medical history may place persons who are not in possession thereof at a disadvantage in diagnosing and treating disorders which are genetically linked ${ }^{98}$, such as, heart diseases; diabetes; hypertension; Alzheimer's; multiple sclerosis; schizophrenia; breast cancer; etc ${ }^{99}$. An examination of a person's family medical history can predict such person's immediate and future health and will assist in detecting such disorders at an early stage ${ }^{100}$. However, one can only acquire an accurate family medical history through one's biological parents. Thus, a child who does not know his or her biological father is denied the right to know such important information ${ }^{101}$.

A lack of not knowing one's genetic origin could also result in death ${ }^{102}$. For example, with organ replacements, genetic relatives are the best donor candidates and, thus a child who is not aware of his or her father's identity could lose out on life saving transplants as their pool of potential donors will be restricted ${ }^{103}$.

Knowing your genetic origin also assists in matters, such as, procreation and marriage. A woman who is not aware of her genetic origin may choose to have children, yet had she known the truth would have opted otherwise. Or, as a consequence of not knowing her genetic origin, could choose to not bear children being under the false impression that she carries a genetic illness ${ }^{104}$.

Uncertainty regarding paternity may furthermore give rise to the possibility of persons who are too closely related marrying one another, or possibly not entering into

98 D.C. Hubin, Daddy dilemmas: untangling the puzzles of paternity, "Cornell Journal of Law \& Public Policy" 2003-2004 13, p. 32-33.

99 D. McRae, Evaluating the effectiveness of the best interests marital presumption of paternity: is it actually in the best interests of children to divorce the current application of the best interests marital presumption of paternity, "Whittier J. Child and Fam. Advoc" 2005-2006 5, p. 374.

100 D. McRae, Evaluating the effectiveness of the best interests marital presumption of paternity: is it actually in the best interests of children to divorce the current application of the best interests marital presumption of paternity, "Whittier J. Child and Fam. Advoc" 2005-2006 5, p. 374.

101 D. McRae, Evaluating the effectiveness of the best interests marital presumption of paternity: is it actually in the best interests of children to divorce the current application of the best interests marital presumption of paternity, "Whittier J. Child and Fam. Advoc" 2005-2006 5, p. 374-375.

102 D.C. Hubin, Daddy dilemmas: untangling the puzzles of paternity, "Cornell Journal of Law \& Public Policy" 2003-2004 13, p. 34.

103 D.C. Hubin, Daddy dilemmas: untangling the puzzles of paternity, "Cornell Journal of Law \& Public Policy" 2003-2004 13, p. 33.

104 D.C. Hubin, Daddy dilemmas: untangling the puzzles of paternity, "Cornell Journal of Law \& Public Policy" 2003-2004 13, p. 34. 
what would be a valid marriage because of the belief that they fall within the prohibited degrees of marriage ${ }^{105}$.

It is evident that the SCA did not consider this in $Y M v L B$ and failed to provide an informed and well reasoned judgment. It is argued that there are obvious benefits to knowing one's genetic origins and that considering this factor in paternity cases will give effect to the best interests of the child.

\section{Conclusion}

A recommendation that legislation should be enacted to govern these scenarios has been made bearing in mind the relevant constitutional rights at stake in a paternity matter ${ }^{106}$. Whether this is possible is yet to be seen. The current reality is that the SCA judgment has resulted in more questions than answers. When will a particular matter amount to a paternity dispute? How does the marital presumption operate in respect of situations similar to the case at hand? How should the constitutional rights involved in such cases be balanced ${ }^{107}$ What is the effect of section 20 of the Children's Act in such matters? ${ }^{108}$ What approach should be followed and which factors should be taken into account in such matters? ${ }^{109}$ Should a child's right to know his or her genetic origin be considered? Another interesting aspect is Part 3 of the Children's Act. It allows minors who fall within a certain age bracket to consent to not only medical treatment and/or operations, but HIV tests as well. Is consent of the guardian really needed for a minor to submit to a DNA test when such a minor (who is of the specified age) has capacity to consent to, for example, an HIV test?

It has been noted that the South African legislature considers blood tests accurate enough to merit the state bearing the costs of the tests in maintenance matters, and thus the courts should be prepared to take judicial notice of the technique and reliability of such tests ${ }^{110}$. In those instances where a man cannot prove sterility for example, it would be difficult to disprove the presumptions that come into play merely because of marriage

105 D.C. Hubin, Daddy dilemmas: untangling the puzzles of paternity, "Cornell Journal of Law \& Public Policy" 2003-2004 13, p. 34-35.

106 B. Van Heerden, et al Boberg's law of persons and the family, Juta: Kenwyn 1999, p. 382.

107 C.M.A. Nicholson, LB v YD 20095 SA 463 (T) /YD v LB (A) 20095 SA 479 (NGP): Disputed paternity, blood tests; court as upper guardian, compel blood tests for DNA testing: best interests of the child "De Jure" 2010, p. 417; E. Bonthuys, What you don't know can't hurt you: the Supreme Court of Appeal and the presumptions of paternity, "South African Law Journal" 2011, p. 434.

108 Vid. E. Bonthuys, What you don't know can't hurt you: the Supreme Court of Appeal and the presumptions of paternity, "South African Law Journal" 2011 in this regard.

109434.

110 J. Heaton, “Juta’s Quarterly Review” October - December 2009 (4). 
or because sexual intercourse at the relevant time was proven or admitted, without the use of the tests ${ }^{111}$.

The SCA failed to do justice to the controversies regarding paternity. The only facet of paternity that has been clarified in the South African context is that a court has inherent power to override a primary care-giver's refusal to submit the child to blood tests. It would appear that a court may also order an adult to submit to DNA/blood tests. However, should the ordering of such tests be the exception that it currently is, rather than the rule? It is argued that it should not. As the SCA did not concern itself with whether blood/DNA tests should be compulsory or not, this question is left unanswered. In any event, this question can only be answered once the other issues regarding paternity have been clarified.

\section{SUMMARY}

\section{Some unresolved complexities in matters involving paternity: a South African Perspective}

A controversial aspect regarding paternity in South African law is whether or not South African Courts are empowered to compel an adult or a minor to submit to DNA/blood tests. The High Courts were not unanimous in this regard, and thus the issue required clarification by the Supreme Court of Appeal (SCA). An opportunity presented itself for the SCA to not only address the issue of the use of DNA/blood tests in paternity matters, but several other issues surrounding paternity. The judgment by the SCA has, it is argued, unfortunately resulted in more questions than answers.

Keywords: paternity; cases; parental rights and responsibilities; genetic origin.

111 Vid. R.W. Darrol, We be of one blood, ye and I"South African Law Journal"1965, p. 318; vid. also Ph.J. Thomas, Paternity; legal or biological concept?, "South African Law Journal" 1988, p. 247 where the author says that proof to rebut the presumption is difficult and sometimes impossible to adduce, which results in a man being considered the father even if this is not the case. 